\title{
The role of bushmeat in a West African agricultural landscape
}

\author{
Justine Shanti Alexander, James McNamara, J. Marcus Rowcliffe \\ JAmes Oppong and E.J. Milner-Gulland
}

\begin{abstract}
There is little information on the changing role of bushmeat hunting in the agricultural areas of West Africa. We assessed the status and role of bushmeat hunting and rural consumption in three communities in Ghana, through household surveys $(n=250)$, and interviews with hunters $(\mathrm{n}=69)$, eatery owners $(\mathrm{n}=18)$ and bushmeat traders $(\mathrm{n}=3)$. Hunting was embedded within dynamic livelihood strategies, with two broad categories of hunters identified: a large group who targeted pests on their own farms using traps, and a smaller group of professional hunters. The professional hunters included a group of young men who hunted with dogs, and another group of older firearm hunters who tended to be members of Hunters' Associations. All professional hunters reported a decline in bushmeat availability and expressed concerns about the viability of hunting as a livelihood. The frequency of consumption of bushmeat increased with distance from the region's main urban centre, Kumasi, but bushmeat was not found to be a major component of the diet in any of the villages. Few men self-identified as hunters, although bushmeat hunting continued to play an important role in the rural economy, primarily for crop protection. Conservation efforts need to consider the full spectrum of hunting behaviours. Specific measures should target forest-based hunters, who are more likely to damage forest ecosystems than crop pest hunters but also show more concern for the sustainability of hunting, and commitment to hunting as an institution.
\end{abstract}

Keywords Agriculture, bushmeat, consumption, Ghana, hunting, livelihoods, West Africa

\section{Introduction}

C onservationists formerly viewed the bushmeat trade as a threat to wildlife without considering the trade's social dimensions and its potential benefits to livelihoods

Justine Shanti Alexander (Corresponding author), James McNamara* and E.J. Milner-Gulland Imperial College London Department of Life Sciences, Silwood Park Campus, Ascot, Berkshire, SL5 7PY, UK

E-mail Justine.s.alexander@gmail.com

J. Marcus RowCliffe Institute of Zoology, Zoological Society of London, Regent's Park, London, UK

JAmes OpPong Ghana Wildlife Division, Forestry Commission, Accra, Ghana

*Also at: Institute of Zoology, Zoological Society of London, Regent's Park, London, UK

Received 29 June 2013. Revision requested 5 August 2013.

Accepted 6 September 2013. First published online 4 August 2014.
(Asibey \& Child, 1990). Since the late 1990s research has increasingly focused on the role played by bushmeat in rural livelihoods (de Merode et al., 2004; Crookes et al., 2007). However, little attention has yet been paid to the role of bushmeat hunting in West Africa's agricultural landscape. Throughout sub-Saharan Africa bushmeat is a valuable natural resource, serving to increase household protein consumption and/or boost household income (Cowlishaw et al., 2005). Many of West Africa's large-bodied mammals have already declined or disappeared and the land has increasingly been converted from forest into agricultural land (Bennett et al., 2006). The time and resources that a household invests in hunting are likely to be highly dependent on the household's agricultural activities (e.g. de Merode et al., 2004; Crookes et al., 2007). Brashares et al. (2011) showed that hunting activity in Ghana varies seasonally, increasing when hunters are not occupied with agricultural work. There is however scant information on the motives underlying these patterns and on how bushmeat hunting may be linked to other activities such as crop protection (e.g. Davies, 1990; Fitzgibbon et al., 1995; Caspary, 1999). Moreover, the role of bushmeat in household subsistence in West Africa's rural areas is not well known (Crookes et al., 2007).

It is likely that both agricultural cycles and rural consumption patterns have an impact on bushmeat hunting in West Africa. Policy options for conserving wildlife, while maintaining bushmeat as a component of rural livelihoods, must be informed by an understanding of who is hunting, their motivations and their dependence on bushmeat both for food and income.

In this study we assessed the role of hunting as a livelihood strategy in three rural communities in Ghana's Ashanti region, two of which are close to the main town of Kumasi, which has a substantial bushmeat market (Crookes et al., 2007), the other further away. Our objectives were: (1) to explore motivations for hunting and the current role of hunting as a livelihood strategy, (2) to assess the role of bushmeat hunting in household meat consumption and bushmeat procurement patterns, (3) to assess changes over time in the role of hunting in livelihoods, and (4) to suggest ways forward for the maintenance of bushmeat species as components of the agricultural landscape.

\section{Study area}

The study took place in Ghana's forest zone, in the Ashanti region of the Upper Guinea Forest Ecosystem, a biodiversity

This is an Open Access article, distributed under the terms of the Creative Commons Attribution licence (http://creativecommons.org/licenses/by/3.0/), 
hotspot primarily consisting of a mixture of secondary forest and agricultural land (Caspary, 1999). Rural livelihoods in the region centre on agriculture, with income primarily derived from cash crops, and crops such as cassava and plantain grown for subsistence (Ghana Statistical Service, 2008). Hunting is an additional activity combined with farming rather than a major occupation in itself (Falconer, 1992; Marfo et al., 2002; Odonkor et al., 2007).

Data were gathered in three villages, Jachie, Kwaman and Anyimaye, during May and June 2011. The first two villages, which are close to Kumasi, the Ashanti region's capital (12 and $48 \mathrm{~km}$, respectively), were identified by the Ghana Wildlife Division as sources of bushmeat to Atwemonom market, Kumasi. Anyimaye is more remote, located on the western outskirts of the Ashanti region $(130 \mathrm{~km}$ from Kumasi). It does not supply significant quantities of bushmeat to Kumasi.

\section{Methods}

\section{Preparation for interviews}

Data were collected through a combination of focus groups $(\mathrm{n}=3)$, household surveys $(\mathrm{n}=250)$, and targeted interviews with hunters $(n=69)$, traders $(n=3)$ and chop bar (eating establishment) owners $(n=18)$. Upon arrival in each village the research team discussed and obtained approval for the research with the chief and the Hunters' Association (a formal network of local hunters). The research objectives were explained to the community through an official announcement. Focus group discussions were then held with hunters, and additional key informant discussions were carried out throughout the fieldwork.

Before the start of all interviews, respondents were asked for consent, following an explanation of the research objectives, assurance that all personal information would remain strictly confidential and an explanation that respondents were free not to answer any questions and to stop the interview or discussion at any time. All interviews were conducted in Twi with the help of an interpreter from Kumasi.

No requests for interviews were declined, and respondents were comfortable about responding to questions about potentially illegal activities (possibly because of the support for the research provided by village leaders and the Hunters' Associations, and also because law enforcement is weak in the area and does not seem to present a concrete threat). The high frequency of hunting reported and the details provided through the household surveys and targeted surveys suggest that any reporting bias was limited.

\section{Focus groups}

The focus group discussions involved eight hunters in Jachie, nine in Kwaman, and 10 in Anyimaye, and were organized with the help of the Hunters' Associations. Firstly, rural livelihoods were discussed, listing the village's main livelihood activities, discussing the community's understanding of seasonality, characterizing the agricultural calendar and ranking the perceived difficulty of each livelihood activity. Next, hunting was discussed as a livelihood option, its seasonality, challenges faced and changes in the importance of hunting as a livelihood source in the previous 10 years. The focus group discussions provided important qualitative information for the finalization of the household and hunter questionnaires.

\section{Household surveys}

Ninety, 87 and 73 (total 250) households in Jachie, Kwaman, and Anyimaye, respectively, were sampled using a systematic sampling scheme. In Jachie and Kwaman households were selected for interview at intervals of 10 households, ensuring that the full geographical area of the village was covered. As Anyimaye is a small community we visited all 80 households but some were not included because the head of the household was not available. To address the first objective of the study, respondents in Jachie and Kwaman were asked to list all the livelihood activities carried out by each adult and then to rank these activities as household income sources. Respondents who did not self-identify as hunters were also asked whether they hired hunters or whether they themselves hunted informally on their farms. Respondents who selfidentified as farmers $(n=45)$ were further asked if during the previous 12 months their crops had been damaged by crop pests and to what extent. A $\chi^{2}$ test was used to test for significant associations between household reports of hunting on farms (yes/no) and the level of crop damage (none, minimal, moderate, severe). In Anyimaye the top three sources of income and types of hunting activity were listed. This facilitated the identification of two broad types of hunters: villagers who self-identified as hunters for a livelihood, whom we refer to as professional hunters, and villagers who engaged in hunting informally on their farms. Households in all three villages were also asked open questions about the reasons for hunting, and closed questions on equipment used and seasonality of hunting.

To address the second objective, households were asked how often (daily, weekly, monthly, once every few months, no longer, never) the household consumed livestock meat, fish or bushmeat, and what species of bushmeat they had consumed most often over the previous 12 months. Given that such a long recall period may lead to recall bias, households were also asked when bushmeat was last consumed, and what species. Finally each household was asked to list and rank, by frequency of use, the sources of any bushmeat consumed. 
TABLE 1 Type, number and age $( \pm S D)$ of hunters surveyed in Kwaman $(n=63)$, Jachie $(n=33)$ and Anyimaye $(n=41)$. Results for farmer hunters are from the household survey; results for professional hunters are from the targeted hunter survey.

\begin{tabular}{|c|c|c|c|c|c|c|c|c|}
\hline & \multicolumn{2}{|c|}{ Farmer hunters } & \multicolumn{6}{|c|}{ Professional hunters } \\
\hline & \multirow[b]{2}{*}{$\mathrm{n}$} & \multirow{2}{*}{$\begin{array}{l}\% \text { of surveyed } \\
\text { households }\end{array}$} & \multicolumn{2}{|c|}{ Fire arms } & \multicolumn{2}{|c|}{ With dogs } & \multicolumn{2}{|c|}{ Total } \\
\hline & & & $\mathrm{n}$ & Age $\pm S D$ & $\mathrm{n}$ & Age \pm SD & $\mathrm{n}$ & Age $\pm S D$ \\
\hline Kwaman & 35 & 40 & 26 & $52 \pm 14.51$ & 2 & $20 \pm 2.1$ & 28 & $48.8 \pm 16.3$ \\
\hline Jachie & 10 & 11 & 16 & $50 \pm 11.17$ & 7 & $34 \pm 12.8$ & 23 & $44.8 \pm 13.5$ \\
\hline Anyimaye & 26 & 36 & 15 & $43 \pm 11.4$ & 0 & & 15 & $43 \pm 11.4$ \\
\hline Total & 71 & 28 & 57 & $49.1 \pm 13.1$ & 9 & $30.8 \pm 12.8$ & 66 & $46.6 \pm 14.4$ \\
\hline
\end{tabular}

\section{Professional hunter surveys}

A total of 69 professional hunters (25 in Jachie, 29 in Kwaman, 15 in Anyimaye), who self-identified as hunting for their livelihood, were selected with the help of the Hunters' Associations and 66 were included in the analysis. To address the study's first objective, hunting practices were explored through questions about hunters' age, membership of a Hunters' Association, usual hunting locations (farm, fallow or forest land) and timing (night, day or both) and size of hunting parties. Hunters were asked to rank species most frequently caught. A typology of professional hunters was developed through questions on hunting strategy and equipment used. Hunters were also asked to list and rank their reasons for hunting, and any additional livelihood activities in order of income generation, what time of year they engaged in hunting, why they pursued hunting during particular months and whether they hunted during times of hardship.

To address the second objective hunters were asked whether they sold or consumed their bushmeat, and to list and rank the outlet where they sold their bushmeat, by frequency of use. The third objective was addressed through questions on changes in the availability and composition of species hunted within the last 10 years. Hunters in Jachie and Kwaman were also asked if they were concerned about the viability of hunting as a livelihood and the reason for any concerns.

\section{Additional targeted surveys}

Finally, structured interviews were held with other actors along the rural commodity chain in each village (three traders and 18 eatery owners) to explore consumer preferences, sources of income and the structure and pattern of bushmeat trade within the villages.

\section{Data analysis}

Statistical tests were conducted using $R \quad v$. 2.13 .1 (R Development Core Team, 2011). Paired Wilcoxon tests, $t$-tests and Fisher's exact tests were used to test for bushmeat consumption between the different communities, differences in the age of firearm hunters and hunters with dogs, and frequency of consumption of bushmeat compared to livestock meat in each village.

\section{Results}

\section{Typology of villagers engaged in hunting activities}

The household interviews confirmed that agriculture was the most common livelihood activity of households $(67 \%$, Jachie; 94\%, Kwaman; 93\%, Anyimaye), and most often ranked first as a source of income (36\%, Jachie; 90\%, Kwaman; 73\%, Anyimaye). Two broad categories of respondents were identified through the household and hunter surveys. The first and largest group, found through the household survey, engaged in hunting activities on their own farms but did not self-identify as hunters. These are referred to here as farmer hunters. The second group, identified through the professional hunters' survey, comprised professional hunters, some of whom used firearms and others hunted with dogs (Table 1).

Farmer hunters reported hunting with traps themselves (7/10 households in Jachie, 18/35 households in Kwaman) or hiring professional hunters to hunt on their farms ( $3 / 10$ households in Jachie, $17 / 35$ of households in Kwaman). Few households ( 2 in Jachie, 5 in Kwaman) had members who explicitly referred to hunting as a livelihood and described themselves as hunters. These were all men and represented a small proportion of the economically active household members in each village. In none of these households was hunting listed as the first source of income for the household. In Anyimaye no households reported hunting as a first or second source of income. Nonetheless, overall, 36\% (26/73) of Anyimaye households reported hunting using traps, guns or dogs.

Of the 66 professional hunters surveyed, 57 hunted with firearms and nine (in Jachie and Kwaman, not in Anyimaye) hunted with dogs. All firearm hunters in the three villages indicated that they primarily caught small ungulate species and rodents, including the grasscutter Thryonomys 
TABLE 2 Characteristics of professional hunters identified in Kwaman $(n=28)$, Jachie $(n=23)$ and Anyimaye $(n=15)$.

\begin{tabular}{|c|c|c|c|c|c|c|c|c|}
\hline & \multicolumn{4}{|c|}{ Firearm hunters } & \multicolumn{4}{|c|}{ Hunters with dogs } \\
\hline & $\mathrm{n}$ & $\begin{array}{l}\text { Mean hours } \\
\text { per hunting } \\
\text { trip } \pm S D\end{array}$ & Timing (\%) & Location (\%) & $\mathrm{n}$ & $\begin{array}{l}\text { Mean hours } \\
\text { per hunting } \\
\text { trip } \pm S D\end{array}$ & Timing (\%) & Location (\%) \\
\hline \multirow[t]{2}{*}{ Kwaman } & 26 & $8.1 \pm 2.84$ & $\begin{array}{l}\text { Day (4) } \\
\text { Night (73) }\end{array}$ & $\begin{array}{l}\text { Farm (23) } \\
\text { Fallow (62) }\end{array}$ & 2 & $10.5 \pm 0.7$ & Day (100) & Farm $(0)$ \\
\hline & & & Both (23) & Forest (15) & & & $\begin{array}{l}\text { Night }(0) \\
\text { Both }(0)\end{array}$ & $\begin{array}{l}\text { Fallow (0) } \\
\text { Forest (2) }\end{array}$ \\
\hline Jachie & 16 & $7.3 \pm 3.33$ & $\begin{array}{l}\text { Day (13) } \\
\text { Night (56) } \\
\text { Both (31) }\end{array}$ & $\begin{array}{l}\text { Farm }(19) \\
\text { Fallow }(81) \\
\text { Forest }(0)\end{array}$ & 7 & $10 \pm 1.5$ & $\begin{array}{l}\text { Day (100) } \\
\text { Night }(0) \\
\text { Both }(0)\end{array}$ & $\begin{array}{l}\text { Farm }(14) \\
\text { Fallow (86) } \\
\text { Forest (14) }\end{array}$ \\
\hline Anyimaye & 15 & $7 \pm 2.36$ & $\begin{array}{l}\text { Day (0) } \\
\text { Night (40) } \\
\text { Both (60) }\end{array}$ & $\begin{array}{l}\text { Farm }(53) \\
\text { Fallow }(47) \\
\text { Forest }(0)\end{array}$ & 0 & & & \\
\hline
\end{tabular}

TABLE 3 List of bushmeat species mentioned by hunters. Legal status is the species' protection under Ghana's Wildlife Law and Regulation.

\begin{tabular}{lll}
\hline Species & Legal status ${ }^{1}$ & Red List status (population trend) $^{2}$ \\
\hline Grasscutter/cane rat Thryonomys swinderianus & Unscheduled & LC (Unknown) \\
Giant rat Cricetomys gambianus & Third Schedule & LC (Stable) \\
Royal antelope Neotragus pygmaeus & Second Schedule & LC (Decreasing) \\
Maxwell's duiker Cephalophus maxwelli & Second Schedule & LC (Decreasing) \\
Bushbuck Tragelaphus scriptus & Second Schedule & LC (Stable) \\
Black duiker Cephalophus niger & Second Schedule & LC (Decreasing) \\
Bay duiker Cephalophus dorsalis & Second Schedule & LC (Decreasing) \\
Tree pangolin Phataginus tricuspis & First Schedule & NT (Decreasing) \\
Brush-tailed porcupine Atherurus africanus & Second Schedule & LC (Unknown) \\
Red river hog Potamochoerus porcus & Second Schedule & LC (Decreasing) \\
Forest elephant Loxodonta cyclotis & First Schedule & VU (Increasing)
\end{tabular}

${ }^{1}$ First Schedule, hunting prohibited; Second Schedule, prohibited in closed season \& no hunting of young/adult with young; Third Schedule, prohibited in closed season; Unscheduled, no restrictions

${ }^{2}$ LC, Least Concern; NT, Near Threatened; VU, Vulnerable (source: IUCN, 2011)

swinderianus, giant rat Cricetomys gambianus, royal antelope Neotragus pygmaeus and Maxwell's duiker Cephalophus maxwelli. All hunters with dogs reported only catching rodent species, including the grasscutter and giant rat. Table 2 provides further details of the hunting practices of professional hunters and Table 3 lists all bushmeat species mentioned by hunters and their legal status under Ghana's Wildlife Law and Regulation.

\section{Hunting as a component of livelihoods}

Farmer hunters, identified using the household questionnaire, reported that they primarily hunted to control pests and not to supplement household income or food (Table 4). They explained how species such as grasscutters and giant rats could cause devastating damage to their food crops, especially during the maize-planting season. Household hunting activity was significantly and positively related to reported crop damage $\left(\chi^{2}=6.45, \mathrm{df}=1, \mathrm{P}=0.011, \mathrm{n}=148\right)$. The farmer hunters reported mainly using traps (81\%,
Kwaman; 80\%, Jachie) and hunted mostly during May-July. This time of year corresponds with the beginning of the maize harvesting season, which according to the interviewed farmers attracts many crop pests.

Most professional hunters reported that they hunted to supplement their incomes (Table 4), although few depended on hunting as their primary source of income $(21 \%$, Kwaman; 17\%, Jachie) and none relied solely on hunting for a living. In Anyimaye most professional hunters indicated that they primarily hunted for food and few reported hunting primarily for income. No professional hunters in Anyimaye used hunting as their primary source of income. In the majority of cases, professional hunters combined hunting with farming (93\%, Kwaman; 87\%, Jachie; $100 \%$, Anyimaye), and few individuals also engaged in another livelihood activity.

Hunting frequency varied throughout the year and the professional hunters described hunting as an important coping strategy in periods of financial stress. Hunting during times of hardship was reported by 49 (74\%) hunters, 
TABLE 4 Primary motives for hunting, reported by hunters in Kwaman $(n=63)$, Jachie $(n=33)$ and Anyimaye $(n=41)$. Results for farmer hunters are from the household survey; results for professional hunters are from the targeted hunter survey.

\begin{tabular}{|c|c|c|c|c|c|c|c|}
\hline \multirow[b]{3}{*}{ Motives } & \multirow{2}{*}{\multicolumn{2}{|c|}{ Farmer hunters }} & \multicolumn{5}{|c|}{ Professional hunters } \\
\hline & & & \multicolumn{2}{|c|}{ Firearm hunters } & \multicolumn{2}{|c|}{ Hunters with dogs } & \multirow[b]{2}{*}{ Overall \% } \\
\hline & $\mathrm{n}$ & $\%$ & $\mathrm{n}$ & $\%$ & $\mathrm{n}$ & $\%$ & \\
\hline \multicolumn{8}{|l|}{ Kwaman } \\
\hline Income & 35 & 6 & 26 & 81 & 2 & 100 & 82 \\
\hline Food & & 3 & & 15 & & 0 & 14 \\
\hline Pest control & & 91 & & 0 & & 0 & 0 \\
\hline Tradition & & 0 & & 4 & & 0 & 4 \\
\hline \multicolumn{8}{|l|}{ Jachie } \\
\hline Income & 10 & 0 & 16 & 75 & 7 & 86 & 78 \\
\hline Food & & 0 & & 25 & & 14 & 22 \\
\hline Pest control & & 100 & & 0 & & 0 & 0 \\
\hline Tradition & & 0 & & 0 & & 0 & 0 \\
\hline \multicolumn{8}{|l|}{ Anyimaye } \\
\hline Income & 26 & 4 & 15 & 7 & 0 & & \\
\hline Food & & 42 & & 93 & & & \\
\hline Pest control & & 54 & & 0 & & & \\
\hline Tradition & & & & 0 & & & \\
\hline
\end{tabular}

mainly as a strategy to smooth income by rapidly raising cash. Only $16(24 \%)$ claimed to hunt all year round, and 29 (44\%) reported hunting throughout August-December, which is the official closed season.

In Jachie and Kwaman the majority ( $74 \%, 31$ individuals) of the firearm hunters reported hunting more frequently in the dry season, during January-March. In the focus group discussions participants indicated that the dry season is a good time to hunt as animals are more easily tracked down in the open vegetation. They added that they were not occupied with farming major cash crops during this period and did not have other jobs to keep them busy. Key informants and the two hunter focus groups identified May-November as the months of heavy agricultural work for maize and cocoa. They asserted that hunting was readily reconciled with the agricultural cycle. In contrast, hunting activity in Anyimaye was more intense during the maize season, when rodents such as grasscutters are more active, and during the rainy season, when antelopes and primate species are more easily located as the forest comes into fruit. The dry season was described as a less favourable season for forest hunting as it is more difficult to approach animals without making a noise on the dry leaves of the forest floor.

The patterns in behaviour of hunters with dogs in Jachie and Kwaman were not so readily identified given the small sample size $(n=9)$. In Jachie all hunters $(n=7)$ reported hunting primarily during June-August, which coincides with the wet season and the start of the heavy agricultural period. Hunting was reported as a full-time occupation during this season given the increased demand by maize farmers seeking help to control crop pests.

\section{Changing role of hunting as a livelihood option}

Focus groups indicated that hunting as a source of income had declined in the past 10 years. All of the hunters interviewed stated there had been a clear decrease in bushmeat availability over the same period. Species reported to be in decline in Jachie and Kwaman included bushbuck Tragelaphus scriptus, black duiker Cephalophus niger, bay duiker Cephalophus dorsalis, tree pangolin Phataginus tricuspis, brush-tailed porcupine Atherurus africanus and the red river hog Potamochoerus porcus. In Anyimaye hunters mentioned that primate species and the forest elephant Loxodonta cyclotis had become rare.

Hunters expressed concern about the viability of hunting as a livelihood because of the reduction in bushmeat availability. In the focus group discussions in Jachie and Kwaman firearm hunters emphasized that hunting had been their primary source of income until a decade or more ago but was no longer a sufficiently reliable source of income. They complained that the longer hours involved and larger distances travelled made it increasingly difficult to do other work the following day. Some also reported that they were getting older, making it difficult to combine hunting with other livelihood activities.

\section{Bushmeat consumption}

Bushmeat was not consumed frequently in any of the villages. Most households surveyed (87\%, Kwaman; 79\%, Jachie; $88 \%$, Anyimaye) reported eating bushmeat but they did so infrequently. No households in Jachie and Kwaman and only one in Anyimaye stated they did so on a daily basis. 
The majority of the households in Jachie and Kwaman ate bushmeat once every few months (52\%, Jachie; 68\%, Kwaman) and only some on a weekly or monthly basis (19 and $27 \%$ in each village, respectively). In Anyimaye consumption of bushmeat was more common, with $44 \%$ of households eating bushmeat on a weekly or monthly basis. Seven and $18 \%$ of households in Kwaman and Jachie, respectively, reported that they previously ate bushmeat but no longer did so. Of the bushmeat species consumed, rodents, especially grasscutters, were mentioned as being the most widely available and frequently consumed (64\%, Kwaman; 53\%, Jachie; 55\%, Anyimaye). Bushmeat consumption was significantly higher in the remote community of Anyimaye than in either Jachie or Kwaman (paired Wilcoxon test, $W=3642.5, \quad \mathrm{P}=0.02, \mathrm{n}=163$, and $W=3,588, \mathrm{P}=0.005, \mathrm{n}=160$, respectively).

In all villages fish (dried, smoked or fresh) was consumed more frequently than bushmeat. It was reported to be part of the daily diet in 99, 90 and 97\% of households surveyed in Kwaman, Jachie and Anyimaye, respectively. Livestock meat was consumed less frequently, with only $24 \%$ of households in Kwaman, $18 \%$ of households in Jachie and no households in Anyimaye reporting that they ate it daily. Levels of consumption of bushmeat were similar to those of livestock meat in Anyimaye (Fisher's exact test, $\mathrm{P}=0.4, \mathrm{n}=73$ ), unlike Jachie and Kwaman, where it was significantly lower (Fisher's exact test, $\mathrm{P}=0.9 \times 10^{-8}, \mathrm{n}=90$ and $\mathrm{P}=6.1 \times 10^{-11}, \mathrm{n}=87$, respectively).

\section{Sourcing of bushmeat}

Bushmeat procurement behaviours varied substantially between villages. Bushmeat was much less easy to procure in Kwaman or Jachie than in Anyimaye. In Jachie, the least remote village, $62 \%$ of households stated they procured bushmeat for household consumption, from the city of Kumasi (30\%), hunters (23\%), local eateries $(20 \%)$, their own farms $(7 \%)$ or other villages $(5 \%)$. The rest obtained bushmeat from the local market but sourced from Kumasi. In the more distant village of Kwaman $76 \%$ of households procured bushmeat for household consumption, obtained primarily from hunters (50\%), specialized traders (35\%) or their own farms (14\%). No bushmeat was sold in the village market. By contrast in the most remote village of Anyimaye, rural households had good access to bushmeat, with most (88\%) households reportedly sourcing bushmeat locally from hunters $(64 \%)$, their own farms $(17 \%)$, eateries $(15 \%)$ or the local market $(3 \%)$.

In Jachie and Kwaman, householders who indicated they did not buy bushmeat complained that hunters rarely sold bushmeat directly to households because they found it more profitable to sell it elsewhere. Many household members observed that they had to hunt on their own land or to know a hunter to obtain bushmeat to prepare at home, otherwise they had to eat prepared bushmeat dishes in eateries.

Professional hunters corroborated these findings. Firearm hunters reported either selling their bushmeat (77\%, Kwaman; 56\%, Jachie; 67\%, Anyimaye) or consuming their bushmeat at home (23\%, Kwaman; 44\%, Jachie; $33 \%$, Anyimaye). The majority of their sales were to local eateries (50\%, Kwaman; 67\%, Jachie) or traders in Kumasi (30\%, Kwaman; 22\%, Jachie). Thus, trade patterns in Jachie and Kwaman were more diversified than in Anyimaye, where all bushmeat was traded locally, usually to households. In the case of Jachie and Kwaman, hunters reported that large ungulate species such as bushbucks were sold almost exclusively to traders in Kumasi. Firearm hunters explained that they obtained a better price and that it was easier to sell their bushmeat as whole carcasses, and occasionally in bulk, to local eateries or traders in Kumasi than directly to households. Similarly hunters with dogs reported selling their bushmeat to Kumasi (50\%, Kwaman; $86 \%$, Jachie) or local eateries (50\%, Kwaman; 14\%, Jachie).

Eatery owners reported rarely selling fresh bushmeat directly to households because it was more profitable to sell prepared dishes. Five of the seven eateries in Kwaman, all six in Jachie and three in Anyimaye reported serving bushmeat dishes all year round. Bushmeat was described as an important component of their business, providing considerable profits. In Anyimaye, however, eateries were not open all week and thus did not appear to represent a major outlet for consumers to access bushmeat.

\section{Discussion}

\section{The role of hunting in livelihoods}

Most studies have focused on the role of bushmeat as a source of income or protein (de Merode et al., 2004; Starkey, 2004). In our study hunting was not reported as a primary source of income for the communities as a whole but trap hunting was important for crop protection, and thus was important indirectly for the livelihoods of farming households by boosting crop production (Ros-Tonen et al., 2005). Trap hunting around fields may therefore play a larger role in the rural economy than previously thought, primarily as a risk mitigation strategy with multiple functions; contributing to income, protein consumption and crop security (Asibey \& Child, 1990; Falconer, 1992). This raises some concerns, given that the use of traps is illegal (Wildlife Conservation Regulation of 1971). The enforcement of this regulation would increase the vulnerability of farmers to crop losses and could negatively affect their livelihoods.

Hunting remained important for the small numbers of professional hunters identified in each village. In Anyimaye hunters indicated that hunting provided a significant source 
of food for their households. However for the professional hunters in the more commercially orientated villages of Jachie and Kwaman, hunting complemented other income sources. This illustrates that bushmeat hunting can still continue to support rural livelihoods to some extent even when wildlife populations become scarce.

Hunters with dogs tended to be young men with diverse livelihood portfolios beyond farming. These hunters were responding to economic signals and the seasonally changing profitability of different activities. In Jachie and Kwaman firearm hunters tended to rely on hunting income mainly during times of low agricultural activity. Hunting thereby potentially served as a safety net. Previous studies (SchulteHerbrüggen, 2010, in Ghana; Solly, 2004, in Cameroon; de Merode et al., 2004, in Democratic Republic of Congo) found similar evidence that bushmeat hunting secured a small but reliable income during the lean agricultural season. These men tended to be older and expressed concern that current declines in wildlife were threatening their hunting incomes. Paradoxically they were the ones who were potentially causing the greatest damage to wildlife populations, by targeting the larger, more vulnerable species, while also appearing to be most committed to hunting sustainability. The fact that some had formed Hunters' Associations suggests they are potentially receptive to participatory approaches to community hunting management and could be the key focus for conservation actions.

The importance of the more traditional approach to hunting, in which firearm hunters hunt in fallow fields and nearby forests, targeting a wide range of forest-dependent species, seems to have declined rapidly over the last decade. In addition it appears to be practised by older men who do not see a bright future in hunting as a livelihood option. In this regard, it is interesting to compare the findings of this study with those of a previous study in different villages but in the same region of Ghana, undertaken in 2002-2004 (Crookes et al., 2007). In that study, $15 \%$ of households reported being involved in hunting, and bushmeat hunting comprised a large proportion $(35 \%)$ of the total village income. In addition only $51 \%$ of hunters (combined from the study's household and hunter surveys) indicated that they hunted rodents and 27 and 6\% indicated that they hunted ungulates and carnivores, respectively (Crookes et al., 2007). This suggests that there has indeed been a decline in bushmeat availability over the last decade, which is eroding the livelihood benefits of bushmeat hunting, corroborating hunters' perceptions of decline.

Our finding that hunting did not represent an important livelihood option in these communities also differs from the earlier findings of Hofmann et al. (1999). They found that hunting provided the sole substantial source of cash income for $71 \%$ of hunters in three Ashanti villages, and only $29 \%$ of hunters had a relatively large farm or farm employment elsewhere. This difference is probably because of declines in the availability of bushmeat. However, given the high price of bushmeat and the low cost of trapping, it is probable that hunting will continue to remain an attractive additional livelihood option, in combination with its pest control function, and with a focus on trapping around fields.

\section{The influence of distance to the urban centre}

The distance to the main urban centre, Kumasi, was expected to have a major effect on the role of hunting in the three communities. It has been suggested that villages with better access to urban areas and exposure to markets have more livelihood options, which could potentially reduce dependence on hunting (Crookes et al., 2007). Creating more employment opportunities in rural areas is thought to decrease dependence on forest resources in two ways: (1) by increasing the opportunity cost of forest resource extraction, hence reducing forest extraction activities, and (2) by increasing household wealth (Illukpitiya \& Yanagida, 2010). Other factors may also be at play, including higher bushmeat prices, which would make hunting a more attractive livelihood option (Damania et al., 2005).

Our study suggests that households in Kwaman and especially in Jachie, located closer to Kumasi than Anyimaye, have a wider range of off-farm livelihood options. Nonetheless some individuals continue to hunt. The incentives for hunters to move away from hunting completely must not yet be sufficient, particularly given that they now have greater opportunities to trade bushmeat in Kumasi. In Anyimaye hunting continues to play a role as a primary livelihood, possibly because other livelihoods are not available.

\section{The role of household consumption}

The role of bushmeat may not only be changing for hunters but also for rural consumers, especially in communities with greater access to Kumasi. Our study indicates that bushmeat was not frequently consumed in any of the villages. This contrasts with the findings of Falconer (1992), who found that $95 \%$ of household members in rural communities in the Ashanti region ate bushmeat and $50 \%$ of household members reported eating bushmeat in the week prior to the interview. These observations, along with reports of a reduction in bushmeat availability from hunters, consumers and eatery owners, suggest that bushmeat consumption has fallen substantially in the villages in the last 2 decades.

There are two possible interacting explanations for the observed low household-level consumption of bushmeat. Firstly, a reduction in wildlife availability has reduced overall supply. Secondly, rural households do not have ready access to fresh bushmeat because it is sold directly to urban consumers or eateries at higher prices than most rural 
households can afford. This is especially the case for larger ungulate species such as bushbucks that tend to be sold almost exclusively to urban centres. Overall the observed low frequency of bushmeat consumption in the study communities seems be a result of a combination of these factors. A household's access to fresh bushmeat, especially in the more rural villages, depended upon their own hunting activities or a close relationship with a hunter.

In Jachie and Kwaman rural household consumption does not therefore appear to be driving local hunting, in contrast to Anyimaye. This was especially the case in the more urbanized Jachie, where households reported rarely obtaining bushmeat from hunters but instead from urban markets, which sourced bushmeat from a wide area.

A more detailed consumer analysis is needed to characterize consumption patterns better in the three villages. In particular, household consumption data need to be complemented and triangulated with data from eatery consumers. Eateries were an important source of demand for bushmeat. Studies that assess consumption within the confines of the household (e.g. through household food diaries or reports from the main food preparer) may therefore underestimate the role of bushmeat in diets in areas undergoing rapid urbanization.

\section{Conclusions and implications for policy}

We have shown that bushmeat hunting continues to play a role in the livelihoods of three rural communities in West Africa: as a means to mitigate pest damage, as a seasonal source of income, as an income safety net and as a source of food. Furthermore, the study suggests that bushmeat hunting and consumption behaviours are dynamic, adapting to changing circumstances over seasons and years. Conservation and development strategies therefore need to consider bushmeat hunting in all its diversity and in the context of other social and economic activities. Solly (2004) also emphasized that policy-makers need to take into account the motives of different types of hunters and to consider the full spectrum of hunting behaviours in developing appropriate conservation and development policies.

Hunters using firearms in fallow and forest habitats target larger-bodied species, thus posing a greater threat to mammal biodiversity than those hunting in fields. More attention and resources should be focused on these hunters, possibly through engagement with Hunters' Associations or similar networks, in an effort to shift hunting towards smaller and less threatened species and to build on their concern regarding the depletion of bushmeat stocks. Conservation efforts should also account for other hunting practices such as hunting related to crop protection. At the moment these practices appear more sustainable, concentrating their efforts on pest management and targeting the less threatened fast-breeding rodent species (Cowlishaw et al., 2005). The current restriction on the use of traps on agricultural land during the closed season may need to be reconsidered while still keeping in mind the need to control the use of traps in forests, where they pose a particular threat to wildlife. Other methods to reduce crop damage could also be explored, to reduce the reliance of farmers on professional hunters. Future research should take into account a wider range of actors and behaviours, to build more consistent linkages between conservation and development policy actions.

\section{Acknowledgements}

JM acknowledges support from the Biotechnology and Biological Sciences Research Council. EJMG acknowledges the support of a Royal Society Wolfson Research Merit Award. We thank the Ghana Wildlife Division, Marc Owusu, Acheompong Brenya, Mr Norga and Mr Akwatia for their help and support in Ghana.

\section{References}

Asibey, E.O.A. \& Child, G.S. (1990) Wildlife management for rural development in sub-Saharan Africa. Unasylva, 161, 1-11. Bennett, E.L., Blencowe, E., Brandon, K., Brown, D., Burn, R.W., Cowlishaw, G. et al. (2006) Hunting for consensus: reconciling bushmeat harvest, conservation, and development policy in West and Central Africa. Conservation Biology, 21, 884-887.

Brashares, J.S., Golden, C.D., Weinbaum, K.Z., Barrett, C.B. \& OKello, G.V. (2011) Economic and geographic drivers of wildlife consumption in rural Africa. Proceedings of the National Academy of Sciences of the United States of America, 108, 13931-13936.

Caspary, H.U. (1999) Wildlife Utilization in Côte d'Ivoire and West Africa-Potentials and Constraints for Development Cooperation. Tropical Ecology Support Program and GTZ, Eschborn, Germany.

Cowlishaw, G., Mendelson, S. \& Rowcliffe, J.M. (2005) Evidence for post-depletion sustainability in a mature bushmeat market. Journal of Applied Ecology, 42, 460-468.

Crookes, D.J., Humphreys, D., Masroh, F., Tarchie, B. \& Milner-Gulland, E.J. (2007) The role of hunting in village livelihoods in the Ashanti region, Ghana. South African Journal of Economic and Management Science, 10, 457-469.

Damania, R., Milner-Gulland, E.J. \& Crookes, D.J. (2005) A bioeconomic analysis of bushmeat hunting. Proceedings of the Royal Society of London B: Biological Sciences, 272, 259-266.

Davies, A.G. (1990) Crop Protection, Sierra Leone: Mammal Ecology. Technical Report 13. Food and Agriculture Organization of the UN, Rome, Italy.

de Merode, E., Homewood, K. \& Cowlishaw, G. (2004) The value of bushmeat and other wild foods to rural households living in extreme poverty in Democratic Republic of Congo. Biological Conservation, 118, 573-581.

Falconer, J. (1992) Non-Timber Forest Products in Southern Ghana. Natural Resources Institute, Chatham, UK. 
Fitzgibion, C.D., Mogaka, H. \& Fanshawe, J.H. (1995) Subsistence hunting in Arabuko-Sokoke forest, Kenya, and its effects on mammal populations. Conservation Biology, 9, 1116-1126.

Ghana Statistical Service (2008) Ghana Living Standards Survey (GLSS 5). Ghana Statistical Service, Accra, Ghana.

Hofmann, T., Elleberg, H. \& Roth, H. (1999) Bushmeat: A Natural Resource of the Moist Forest Regions of West Africa with Particular Consideration of Two Duiker Species in Cote d'Ivoire and Ghana. TöB Publication number TöB F-V/7e. GTZ, Eschborn, Germany.

Illukpitiya, P. \& Yanagida, J.F. (2010) Farming vs forests: trade-off between agriculture and the extraction of non-timber forest products. Ecological Economics, 69, 1952-1963.

IUCN (2011) The IUCN Red List of Threatened Species v. 2011. Http:// www.iucnredlist.org [accessed 17 August 2011].

Marfo, K., Anchirinah, V. \& Wiggins, S. (2002) Environmental Policies and Livelihoods in the Forest Margins of Southern Ghana. Crops Research Institute, Kumasi, Ghana.

Odonkor, S., Grogdo, F., Attuquayefio, D. \& Bimi, L. (2007) The wildlife trade in Ghana: a threat to biodiversity conservation. Ghana Journal of Science, 47, 101-106.

R Development Core Team (2011) R: A Language and Environment for Statistical Computing. Http://www.r-project.org [accessed 10 July 2014].

Ros-Tonen, M.A.F., ZaAl, F. \& Dietz, T. (2005) Reconciling conservation goals and livelihood needs: new forest management perspectives in the 21st century. In African Forests Between Nature and Livelihood Resources: Interdisciplinary Studies in Conservation and Forest Management (eds M.A.F. Ros-Tonen \& T. Dietz), pp. 3-29. Edwin Mellen, Lewiston, New York, USA.

Schulte-HerbrÜgGen, B. (2010) The importance of bushmeat in the livelihoods of cocoa farmers living in a wildlife depleted farm-forest landscape, SW Ghana. PhD thesis. Imperial College London, and Zoological Society of London, London, UK.

Solly, H. (2004) Bushmeat Hunters and Secondary Traders: Making the Distinction for Livelihood Improvement. ODI Wildlife Policy Briefing 8.

STARKEY, M. (2004) Commerce and subsistence: the hunting, sale and consumption of bushmeat in Gabon. $\mathrm{PhD}$ thesis. University of Cambridge, Cambridge, UK.

\section{Biographical sketches}

Justine Alexander is studying inter-specific interactions of carnivores in high elevation areas of China. JAmes MCNAMARA developed an interest in conservation and bushmeat research when working on a chimpanzee conservation project in Guinea, West Africa. MARCUS ROWCLIFFE has been involved in bushmeat research since 1999, when he co-founded the ZSL Institute of Zoology bushmeat research programme. JAMES OPPONG has worked for the Ghana Wildlife Division for 13 years. E.J. Milner-Gulland has broad interests in conservation and the interaction between resource users and wildlife populations. Her research group's website is www.iccs. org.uk. 